\title{
Southern elephant seals from Kerguelen Islands confronted by Antarctic Sea ice. Changes in movements and in diving behaviour
}

\author{
Frédéric Bailleul ${ }^{a,{ }^{*}}$ Jean-Benoit Charrassin ${ }^{b}$, Robert Ezraty $^{c}$, Fanny Girard-Ardhuin ${ }^{c, d}$, \\ Clive R. McMahon ${ }^{\mathrm{e}}$, Iain C. Field ${ }^{\mathrm{e}}$ and Christophe Guinet ${ }^{\mathrm{a}}$ \\ ${ }^{a}$ Centre d'Etudes Biologiques de Chizé, Centre National de la Recherche Scientifique, 79360 Villiers \\ en Bois, France \\ ${ }^{\mathrm{b}}$ Equipe Physique de l'Océan Austral, DMPA, Muséum National d'Histoire Naturelle, Paris, France \\ ' Laboratoire d'Océanographie Spatiale, IFREMER B.P. 7029280 Plouzané, France \\ ${ }^{d}$ Centre National d'Etudes Spatiales, 2 place Maurice Quentin, 75001 Paris, France \\ ${ }^{\mathrm{e}}$ Antarctic Wildlife Research Unit, School of Zoology, University of Tasmania, P.O. Box 252-05, \\ Hobart, Tasmania 7001, Australia
}

*: Corresponding author : Tel : (33) 549099603 ; Fax : (33) 549096526 ; email : bailleul@cebc.cnrs.fr

\begin{abstract}
:
The behaviour of southern elephant seals from Kerguelen Island (4950'S, 7030'E) was investigated in relation to the oceanographic regions of the Southern Ocean. The oceanographic and the seal behaviour data, including location and diving activity, were collected using a new generation of satellite-relayed devices measuring and transmitting pressure, temperature, and salinity along with locations. Dive duration, maximum diving depth, time spent at the bottom of the dives, and shape of dive profiles were compared between male and female seals, and were related to the oceanographic characteristics of areas prospected by the seals. Most animals travelled to the Antarctic shelf. However, during winter, adult females travelled away from the continent, remained and foraged within the marginal sea-ice zone, while juvenile males remained within the pack ice to forage mainly on the Antarctic shelf. Therefore, as the ice expanded females appeared to shift from benthic to pelagic foraging farther north, while males continued to forage almost exclusively benthically on the continental shelf. This difference is likely related to the different energetic requirements between the two sexes, but also may be related to pregnant females having to return to Kerguelen in early spring in order to give birth and successfully raise their pups, while males can remain in the ice. Our results show an important link between elephant seals and Antarctic sea ice and suggest that changes in seaice conditions could strongly affect the behaviour of this species.
\end{abstract}

Keywords: Marine ecology; Temperature profiles; Benthic environment; Pelagic environment; Diving Behaviour; Mirounga leonina 


\section{Introduction}

Within ocean ecosystems, food resources are patchily distributed in space and time and their distribution generally reflects the heterogeneity of physical and biological features of the ocean (bathymetry, sea surface temperature, primary productivity), as shown for seabirds (Pakhomov and MacQuaid, 1996; Bost et al., 1997; Guinet et al., 1997; Weimerskirch, 1998) and pinnipeds (MacConnell et al., 1992; Loeb et al., 1997; Guinet et al., 2001). In the Antarctic zone, defined here as the vast area located between the Polar Front (PF) and the Antarctic continent, several oceanographic regions have been described. Along a North South transect, several hydrological fronts have been identified and defined by oceanographers according to their vertical temperature gradient. These fronts divide the Southern Ocean in several bio-geographic regions (Park et al., 1998b). The seasonal variation of sea ice extent is an important feature of the dynamics of the Southern Ocean and thus affects the oceanographic conditions, as well as determining the bio-geography of a key Antarctic species such as krill (Loeb et al., 1997).

Southern elephant seals (Mirounga leonina) have a circumpolar distribution breeding on subantarctic Islands, close to the PF, and travelling over large distances to forage, often in the sea ice area (Gales and Burton, 1989; Bornemann et al., 2000; McMahon et al., 2005a). They dive continuously and deeply along their foraging trip (Hindell et al., 1991b). Adult elephant seals are characterized by an important sexual size dimorphism. Males are on average five to six times larger than females and can presumably handle larger prey. On the basis of size alone, a $2500 \mathrm{~kg}$ male has a daily energy requirement three times that of a $500 \mathrm{~kg}$ female (Boyd et al., 1994). Therefore, adult males may adopt different behaviours (Hindell et al., 1991b; MacConnell and Fedak, 1996; Campagna et al., 1999) to meet their higher 
energetic requirements. Thus, it is expected that male and female southern elephant seals will differ in their foraging ecology.

Marine mammals impose stringent constraints on technologies for providing information on their biology while at sea. The rigours of their environment, their potentially enormous range and the fact that they spend most of their time below the surface at great depths, where both direct observation and telemetry are difficult, requires the use of novel techniques. The development of the data logger and transmitter package has provided a methodology which yields both high quality location and behavioural data. This has permitted visualization of the movements of marine mammals as they move freely through the most remote reaches of ocean (McConnell et al., 1992; Bonadonna et al., 2001; Fedak et al., 2002; Matthiopoulos et al., 2004). Recently the Sea Mammals Research Unit in Scotland developed a new Argos - CTD (Conductivity Temperature Depth) satellite relayed device to investigate the diving behaviour of elephant seals in relation to their environment. This new generation of logger transmits the collected information by satellite almost in real time and allows interpretation of the pelagic behaviour in terms of the immediate oceanic environment (Fedak 2004, McMahon et al., 2005b).

The aim of this study was to investigate how the foraging activity of elephant seals is distributed within the oceanographic regions of the Southern Ocean. Several studies have shown that foraging activity and non foraging activity such as travelling can be discriminated on the basis of the shape of the dive. For example Hindell et al. (1991b) and Crocker et al. (1997) have determined that travelling dives are generally V-shaped dives while foraging dives are generally $\mathrm{W}$-shaped or benthic square shaped dives.

The different oceanographic regions were determined according to the temperaturedepth profiles measured by the elephant seals while diving. Sexual differences in foraging distribution and diving behaviour are also investigated. However, because such differences 
could also result from a size effect, we compared the foraging behaviour of males and females of similar mass and size.

\section{Materials and methods}

\subsection{Device and sensors}

Water temperature, salinity and depth were collected with a Satellite Relayed Data Logger (SRDL) equipment manufactured by Sea Mammals Research Unit (Scotland). These devices were microprocessor-controlled recordings units, each of which was equipped with a pressure transducer (accuracy of $\pm 5 \mathrm{dbar}$ ), a temperature probe $\left( \pm 0.0011^{\circ} \mathrm{C}\right.$ resolution and $0.01{ }^{\circ} \mathrm{C}$ accuracy), a conductivity sensor $( \pm 0.003 \mathrm{~ms} / \mathrm{cm}$ resolution $)$ and a real time internal clock. All sensors were housed in a small $105 \times 70 \times 40 \mathrm{~mm}$ piece of resin weighing about $370 \mathrm{~g}$. The housings were pressure-rated to $2000 \mathrm{~m}$. Data were sampled every 5 seconds but the limited Argos data system did not enable all records to be transmitted. A pseudo-random method to schedule the transmission of an unbiased data sample of the stored records was used (Fedak 2004). To compress dive profile information from time-depth records, a method developed by Fedak et al. (2001) was used. The four time-depth points where the dive shape changed most rapidly (tie points) were selected. The profile was reconstructed by linear interpolation between the tie points. For temperature profiles, twelve data points were recorded from the maximum depth level to the surface for each dive on the up-cast; two to four profiles were transmitted each day. For this study, only the temperature profiles were used to characterize the oceanographic sectors. A dive's bottom phase defined as the time spent at depths greater or equal $80 \%$ of maximum the depth was used to complete the analysis (Lesage et al., 1999; Schreer et al., 2001). 
119 From December 2002 until January 2003 and from January to March 2004, twelve SRDL's

120 were deployed at Kerguelen Islands: seven juvenile males and five adult females ending

121 moult were equipped.

122 All seals were caught with a canvas head-bag and anaesthetized with a 1:1 combination of

123 Tiletamine and Zolazepam (Zoletil 100) injected intra-venously (McMahon et al., 2000; Field

124 et al., 2002). The recorders were glued on the head of seals, using beds of quick-setting epoxy

125 (Araldite AW 2101), once the hair had been cleaned with acetone.

\subsection{Environmental satellite data}

128 To complement the set of oceanographic data collected by the animals themselves, satellite

129 remote sensing data were also used. Sea ice is an important oceanographic parameter when 130 investigating the foraging ecology of Antarctic predators. Satellites enable daily and global 131 coverage of the polar oceans, providing an unique monitoring capability of sea ice. Ice 132 concentration maps were computed with a ground resolution of $6.25 \mathrm{~km} \mathrm{x} 6.25 \mathrm{~km}$. The daily 133 maps of ice concentration were produced by the University of Bremen (Germany) and 134 provided to IFREMER (France) for regional processing and analysis.

135 An estimate of the ocean depth derived from the Smith and Sandwell (1997) dataset was used 136 and enables the identification of benthic dives.

\subsection{Dives classification}

139 Despite the crude resolution of the dive profiles recorded some commonly recurring shapes 140 could be easily identified and used for sorting the 55000 dive profiles. Six distinct dive types 141 were defined on the basis of the general shape of the dive profile. The main parameters used 142 to sort the dive profiles were the slopes (S) of the interpolated profile and the vertical distance 
143 (D) between the tie points (Fig 1a). To ease the classification process, a program was written 144 using the R package (ver. 1.8.1; Ihaka and Gentleman, 1996). The six profiles categories are

145 illustrated in figure 1b. Square dives are often considered as benthic dives but the

146 confrontation of the diving depth against bathymetry at the corresponding location clearly

147 indicated that square dives were not always benthic dives. Therefore, benthic dives were

148 defined according to the diving depth and the corresponding ETOPO bathymetry. The 149 changes in the frequency of dive types performed, according to the areas prospected, allowed 150 to analyze the diving behaviour of all individuals.

\subsection{The boundary of areas prospected}

153 To identify different frontal structures, oceanographers typically create temperature and

154 salinity sections using data from CTD measuring instruments deployed at sequences of 155 locations along the tracks of ships. In this study such measurements were carried out directly 156 by elephant seals. From temperature/depth profiles recorded daily, a vertical

157 temperature/depth section was interpolated along the trip for each seal and used to identify the

158 hydrological fronts and the corresponding oceanographic regions (Fig 2).

159 The PF area is defined, conveniently, by the northernmost extent of the subsurface 160 temperature minimum bounded by the $2^{\circ} \mathrm{C}$ isotherm at the $100-300 \mathrm{~m}$ depth band (Park et al., 161 1993; Belkin and Gordon, 1996).

162 Although the northernmost extent of pack ice is generally inferred from a sudden drop of

163 surface salinity, Klyausov (1993) remarked on a noticeable change in surface temperature (by

$164 \quad 1.5-2^{\circ} \mathrm{C}$ ) across the boundary and a temperature of $-0.5^{\circ} \mathrm{C}$ within the minimum temperature 165 layer. We used this latter observation to define the winter ice limit.

166 South from the PF, isolines of subsurface temperatures shoal gradually toward the Antarctic 167 Divergence (AD), but south of AD they deepen abruptly toward the Antarctic continental 
margin, showing an asymmetric dome-like structure. Hence, the AD is defined as the summit

169 position of this asymmetric dome-like structure (Park et al., 1998a) (Fig 2).

170 On the continental shelf, the water characteristics are completely different from those further

171 offshore. The boundary between shelf water and offshore water is the Antarctic Slope Front

172 (ASF) (Jacobs, 1991), which develops on the upper continental slope just seaward of the shelf

173 break.

174 In this study, we defined three main habitats by combining the in situ bathymetry data, 175 temperature data collected by seals (Fig 2) and satellite information on sea ice concentration :

176 The pelagic area refers to the sector located between the PF and the AD.

177 Within this area two different habitats were distinguished : i) open water free of sea ice, ii) the

178 sea ice marginal zone (i.e. the outer-edge of pack-ice ).

1792 The Antarctic slope area refers to the part between the AD and the ASF with 180 depths between $500 \mathrm{~m}$ and $1000 \mathrm{~m}$,

1813 The Antarctic shelf area refers to the zone south from the ASF, where the water 182 temperature is colder, relatively homogeneous in the layer and depth are less than $500 \mathrm{~m}$.

\subsection{Statistical analysis}

185 Two males ( $\mathrm{n}^{\circ} 7$ and $\mathrm{n}^{\circ} 10$, Fig 3 a) for which recording duration were low $(<30$ days) have

186 been removed of the analysis. We compared diving behaviour of the remaining males and

187 females according to oceanographic areas in terms of dive duration, maximum dive depth,

188 time spent at the bottom of the dive and proportion of dive profile types performed (Table 1)

189 using General linear mixed models (Glmm) in the R package and including individuals as a 190 random variable. The Akaike Information Criteria (AIC) allowed to select the most 191 parsimonious model (Burnham and Anderson 2002), the best-fit model having the lowest AIC 192 value. To determine the effect of any term in selected models, we used a $\chi^{2}$ analysis of 
deviance. To avoid the effects of the serial autocorrelation inherent in diving data, it is

194 possible theoretically to incorporate the degree of autocorrelation into the Glmm structure.

195 However the low number of individuals compared to the great number of parameters tested,

196 did not allow such models to be run. Therefore, we removed a part of the data according to

197 the degree of autocorrelation via random subsets.

198

199

\section{Results}

200

201

The following results were computed for five females and five males. Weight and size of 202 animals equipped did not differ for either sex (males mean body mass $=372.9 \pm 69.5 \mathrm{~kg}$, females mean body mass $=339.7 \pm 43.0 \mathrm{~kg}, \mathrm{U}=8, \mathrm{p}=0.42$ and males mean size $=2.6 \pm 0.2$ $\mathrm{m}$, females mean size $=2.4 \pm 0.1 \mathrm{~m}, \mathrm{U}=5.5, \mathrm{p}=0.17$ ). All but one elephant seals spent time on the Antarctic shelf (Fig 3 a \& b). One female ( $n^{\circ} 2$, Fig 3 a) remained in pelagic waters.

\subsection{Time spent by area}

Recording duration was $145 \pm 67$ days on average across all individuals. No difference was observed between males and females in recording duration. Females spent more time in the pelagic area than males (females : $84.1 \pm 16.1 \%$, males : $34.8 \pm 13.9 \%, \mathrm{U}=25, \mathrm{p}=0.009$ ).

However, among the individuals who went to the Antarctic sector, females spent more time in

212 the sea ice marginal zone than males (females : $60.4 \pm 18.7 \%$, males : $16.7 \pm 16.8 \%, \mathrm{U}=12$,

$213 \mathrm{p}=0.034)$. In contrast, males spent more time within the Antarctic shelf area than females

214 (females : $8.8 \pm 10.0 \%$, males : $37.0 \pm 19.9 \%, \mathrm{U}=2, \mathrm{p}=0.028$ ), while no difference 215 between sexes was observed in the proportion of time spent within the Antarctic slope area 216 (females : $4.0 \pm 5.4 \%$, males : $8.1 \pm 6.5 \%, \mathrm{U}=8, \mathrm{p}=0.346$ ). 


\subsection{Influence of sea ice}

219 As sea ice expanded from the continent towards the North during winter, the tracks of females began to differ from those of males. Males remained on the Antarctic shelf area despite sea

221 ice, while females remained within the sea ice marginal zone close to the open sea (Fig 3a \& 3b). There was a strong correlation $\left(\mathrm{r}^{2}=0.92, \mathrm{p}<0.001\right)$ between the distance of females

223 from the continent and distance between the continent and the sea ice marginal zone, as 224 illustrated by the one to one regression line of figure $3 \mathrm{a}$, while no correlation was observed 225 for the males $\left(\mathrm{r}^{2}=0.007, \mathrm{p}=0.600\right)$.

\subsection{Diving behaviour}

228 We fitted several models for all the parameters presented in table 1, including the sex and 229 then the areas as control variables and we compared the results.

\subsubsection{Maximum depth}

232 The most parsimonious model showed a strong area effect, which was significant in our 233 analysis of deviance $\left(\mathrm{AIC}=309.45, \chi^{2}=10.05, p=0.0015\right)$. This implies that there was a 234 significant difference in the maximum depth reached by the seals in the different areas visited, 235 while no effect of sex was observed. Seals dived deeper on the talus (477 $\pm 94 \mathrm{~m})$ than in the 236 pelagic area $(385 \pm 31 \mathrm{~m} ; \mathrm{t}$-value $=2.604, p=0.02)$, while no difference was observed 237 between the pelagic area and the plateau $(350 \pm 47 \mathrm{~m}$; $\mathrm{t}$-value $=0.921, p=0.37)$.

\subsubsection{Dive duration and Bottom time}

240 No sex and area differences were observed in the dive duration and in the time spent at the 241 bottom of dives for any of the dive type categories. The overall average dive duration was 19 $242 \pm 4 \mathrm{~min}$, while the overall average bottom time was $9 \pm 2 \mathrm{~min}$ for all the individuals. 
However, despite the lack of significant difference in the bottom time between areas, it seems

244 that seals tended to spend 1 min more on average on the plateau than in other areas, regardless

245 of the dive type categories.

\subsubsection{Proportion of dive profile types performed}

248 There were not significant differences in the proportion of U-shape, V-shape and SqR-shape 249 dives performed. However, the proportion of W-shape, Square and Drift dives vary 250 significantly between the areas, while no sex effect was observed. Indeed, the most 251 parsimonious models showed strong area effects on these three dive types, which were 252 significant in our analysis of deviance $\left(\mathrm{AIC}=198.24, \chi^{2}=5.30, p=0.02 ; \mathrm{AIC}=185.02, \chi^{2}=\right.$ $2538.44, p=0.004 ;$ AIC $=146.60, \chi^{2}=9.81, p=0.002$ respectively). Seals performed on 254 average a greater proportion of $\mathrm{W}$-shape dives in pelagic area (t-value $=2.28, p=0.039)$, 255 while they performed a greater proportion of Square and of Drift dives on the plateau $256 \quad($ respectively $\mathrm{t}$-value $=3.44, p=0.004$ and $\mathrm{t}$-value $=3.53, p=0.003$ ).

\section{Discussion}

260 This study reveals differences in the track patterns and in the diving behaviour of male and 261 female southern elephant seals. The comparisons may only be considered as indicative 262 because of the small size of the samples, but some important differences are revealed by this 263 study.

\subsection{Behavioural differences}

266 Nine out of the ten elephant seals we considered in our analysis went to the Antarctic 267 continent edge from Kerguelen Islands. One female travelled and remained exclusively in the 
pelagic area in the vicinity of the PF zone. Previous studies on pinnipeds have shown that V-

269 shape dives were associated with a travelling activity, U-shape have been considered as both

270 foraging and resting in pelagic phocids that spend long periods of time away from land,

271 square-dives as benthic foraging dives, while W-shape and SqR-shape dives were associated

272 with a foraging activity (Hindell et al., 1991b; Le Boeuf et al., 1992; Schreer and Testa, 273 1996). When they reached the vicinity of the Antarctic continent, both males and females 274 initially concentrated their activities in the vicinity of the Antarctic slope and plateau. In these 275 areas, they encountered a noticeable changes in oceanographic conditions from those found in 276 the pelagic area, such that water temperature and bottom depth decreased drastically. All of 277 the benthic dives observed in this study occurred in these areas and individuals seemed to 278 spend more time at the bottom of dives on the shelf. This suggests a benthic foraging activity 279 for both males and females (Hindell et al., 1991b). However, thereafter the distribution of 280 both sexes showed some striking differences in relation to the change of sea ice conditions as 281 winter progressed. Males concentrated their activity on the Antarctic plateau, despite the 282 presence of pack-ice, while females left this area and moved north as the sea ice extended 283 northwards. Females remained located within the sea ice marginal zone during this period, as 284 suggested by the linear relationship found between the distance of females from the continent 285 and the distance of the sea ice marginal zone to the continent over the sea-ice extension 286 period. Although most of the males and females went to similar oceanographic areas, sea-ice 287 extension determined the time spent within each of these areas. Thus, depending on their 288 location, females foraged benthically and pelagically while males tended to forage benthically 289 throughout their stay on the Antarctic shelf. Similar results were found for post-moult adult 290 females in South Georgia (McConnell and Fedak, 1996), in Patagonia (Campagna et al., 291 1999), in Marion Island (Jonker and Bester, 1998) and in Macquarie Islands (Hindell et al., 292 1991a). 
294 Sea ice locality presents particular environmental conditions which could explain the presence 295 of richer habitats. According to Park et al. (1998a), winds change across the AD, from 296 westerly winds in the north to easterly winds in the south. The strongest upwelling of the 297 Circumpolar Deep Water (CDW) is thus expected at the AD. Moreover, the ASF is the 298 primary site for exchange and mixing of the shelf water and the upwelled CDW. Such 299 circulations of the water masses induce the transport of particles in the water column and 300 favour the development of primary producers and primary consumers, which are at the root of 301 the global food web (Gage and Tyler, 1991). Although some lags may partially decouple top 302 predators from primary production, it follows that male and female seals are likely to and 303 indeed from our observations they do target the Antarctic shelf and slope areas due to their 304 higher productivity compared to adjacent waters. But it is unclear why females do not remain 305 in this productive area for the duration of their Antarctic foraging trip. One possible 306 explanation is that female seals could become trapped within high sea ice concentrations of 307 pack ice, then being unable to travel to the open sea. Another explanation may be due to the 308 temporal constraint of the breeding period, i.e. giving birth in October at Kerguelen Islands, 309 and the time it takes females to travel back to their breeding islands and so doing the females 310 avoid the risk of being trapped by sea ice. However, this assumption needs to be treated with 311 some caution because other studies suggested that adult females are able to spend most of the 312 winter well within the sea ice zone (Bradshaw et al., 2003 ).

\section{4.3. Energetic requirements}

315 The Antarctic shelf and slope areas are clearly highly productive but some other studies have 316 also shown that the edge of pack-ice is a productive area during the winter period (Smith and 317 Nelson, 1985; Ainley and DeMaster, 1990). Moreover, not only are there differences in 
318 productivity in these regions but, these different regions also differ in their composition in terms of the prey composition available to elephant seals (Bradshaw et al., 2003). Therefore resources between the edge of pack-ice and the Antarctic shelf are probably quite different. As the foraging behaviour and distribution of marine predators is influenced largely by the distribution of their prey, the sexual differences in movements observed in our study could possibly be related to the different energetic requirement between juvenile males and adult females. Field et al. (2005) have shown that juvenile females tended to metabolize relatively more lean tissue than juvenile males. This difference in metabolism is related to growth rate and precocious development for females. Within adults, differences in metabolism have been related to the costs of breeding (Boyd 2002; Beck et al., 2003), typically greater for females.

328 Therefore, in our study, adult females may have targeted the edge of pack-ice to increase their

329 body reserve in the form of fat for the upcoming breeding effort, while males metabolized 330 probably lean tissue, remaining on the shelf, to invest more in growth. To confirm this 331 hypothesis, it would be necessary to study the foraging distribution of juvenile females and 332 adult males, to deeper investigate the physiology of this species in Kerguelen and to study the 333 diet of males and females in details by using complementary methods (stable isotopes, fatty 334 acids...).

\subsection{Conclusion}

337 The Antarctic marine ecosystem experiences some important changes during winter because 338 of sea-ice extent. Previous studies showed that krill reproduction and survival are 339 significantly affected by the extent and duration of the ice cover (Loeb et al., 1997). Such 340 changes could obviously have adverse affects on populations of the main krill predators (Reid 341 and Croxall, 2001), as probably other trophic levels in the Antarctic food web. Even if 342 elephant seals are not, a priori, direct krill predators (Rodhouse et al., 1992; Slip, 1995), it 
343 appears clearly that they interact with the ice environment during winter and that they depend 344 on the changes in sea ice conditions, though they breed on a sub-Antarctic Island. Because of 345 restricted ship access, relatively little is known about the distribution of prey during winter, 346 particularly in the central parts of pack ice regions, where males are located. Monitoring how 347 the changes in sea ice conditions affect the behaviour of this species and the prey availability 348 is a future challenge for the conservation of the biggest seals in the world. 
This work was supported by Institut Paul Emile Victor (IPEV), the Territoire des 351 Terres Australes et Antarctiques Françaises (TAAF) and the Region Poitou-Charentes. The 352 authors would like to thank the members of the $53^{\text {th }}, 54^{\text {th }}$ and $55^{\text {th }}$ research mission at 353 Kerguelen Island for their assistance in the field. We are grateful to Dr Heygster (University 354 of Bremen, Germany, http://iup.physik.uni-bremen.de:8084/amsr/amsre.html) for making 355 available the AMSR-E data. Bathymetry data are collected from ETOPO 5 database 356 (http://www.ngdc.noaa.gov/ngdc.html). We wish particularly to thank, M. Biuw and M. 357 Hindell for their useful comments and all the members of the Centre d'Etudes Biologiques de 358 Chizé for their day to day assistance. F. Roquet and Y.-H. Park provided an efficient 359 assistance for treatment and analyse of seal temperature data. Many thanks to C.J.A. 360 Bradshaw and M.A. Fedak, the two reviewers, for correcting and shaping this manuscript. 
Ainley, D.G., Demaster, D.P., 1990. Upper trophic levels in polar marine ecosystems. In : W.O., Smith Jr (Eds.), Polar Oceanography Part B Chemistry, biology and geology. San Diego, CA : Academic Press, 599630.

Belkin, I.G., Gordon, A. L., 1996. Southern Ocean fronts from the Greenwich meridian to Tasmania. Journal of geophysical research 101, 3675-3696.

Beck, C.A., Bowen, W.D., Iverson, S.J., 2003. Sex differences in the seasonal patterns of energy storage and expenditure in a phocid seal. Journal of Animal Ecology 72, 280-291.

Bonadonna, F., Lea, M. A., Dehorter, O., Guinet, C., 2001. Foraging ground fidelity and route-choice tactics of a marine predator: the Antarctic fur seal Arctocephalus gazella. Marine Ecology Progress Series 223, 287-297.

Bornemann, H., Kreyscher, M., Ramdohr, S., Martin, T., Carlini, A., Sellmann, L. and Plötz, J., 2000. Southern elephant seal movements and Antarctic sea ice. Antarctic Science 12, 3-15.

Bost, C-A., Georges, J.Y., Guinet, C., Cherel, Y., Pütz, K., Charrassin, J-B., Handrich, Y., Zorn, T., Lage, J. and Le Maho, Y., 1997. Foraging habitat and food intake of satellite-tracked king penguins during the austral summer at Crozet Archipelago. Marine Ecology Progress Series 150, 21-33.

Boyd, I.L., Arnbom, T.A., Fedak, M.A., 1994. Biomass and energy consumption of the South Georgia stock of southern elephant seals. In : B.J. Le Boeuf and R.M. Laws (Eds.), Elephant seals: population ecology,

Boyd, I.L., 2002. Energetics: consequences for fitness. In : A.R. Hoelzel (Eds.), Marine Mammal Biology: An Evolutionary Approach. Blackwell Science, Carlton.

Bradshaw, C.J.A., Hindell, M.A., Best, N.J., Phillips, K.L., Wilson, G., Nichols, P.D., 2003. You are what you eat: describing the foraging ecology of southern elephant seals (Mirounga leonina) using blubber fatty acids. Proceedings of the Royal Society of London - Series B: Biological Sciences 270, 1283-1292.

Burnham, K.P., Anderson, D.R., 2002 Model Selection and Multimodal Inference: A Practical InformationTheoretic Approach, 2nd edn. Springer-Verlag, New York, USA. male southern elephant seals from Patagonia. Journal of. Mammalogy 80(4), 1341-1352 
Crocker, D.E., Le Boeuf, B.J., Costa, D.P., 1997. Drift diving in female northern elephant seals: implications for food processing. Canadian Journal of Zoology 75, 27-39.

Fedak, M.A., 2004. Marine mammals as platforms for oceanographic sampling: a "win/win" situation for biology and operational oceanography. Memoirs of the National Institute of Polar Research, Special Issue 58, 133-147

Fedak, M.A., Lovell, P., Grant, S.M., 2001. Two approaches to compressing and interpreting time-depth information as collected by time-depth recorders and satellite-linked data recorders. Marine Mammal Science 17, 94-110.

Fedak, M.A., Lovell, P., McConnell, B.J., Hunter, C., 2002. Overcoming the constraints of long range radio telemetry from animals: getting more useful data from smaller packages. Journal of Integrative and Comparative Biology 42(3) 3-10 (formerly American Zoologist).

Field, I.C., Bradshaw, C.J.A., McMahon, C.R., Harrington, J., Burton, H.R., 2002. Effects of age, size and condition of elephant seals (Mirounga leonina) on their intravenous anaesthesia with tiletamine and zolazepam. Veterinary Record 151, 235-240.

Field, I.C., Bradshaw, C.J.A., Burton, H.R., HINDELL, M.A., 2005. Juvenile southern elephant seals exhibit seasonal differences in energetic requirements and use of lipids and protein stores. Physiological and Biochemical Zoology 78, 491-504.

Gage, J.D., Tyler, P.A., 1991. The development of deep-sea biology, the physical environment and methods of study. In : J.D. Gage and P.A. Tyler (Eds.), Deep-Sea Biology : A natural History of Organisms at the Deep-Sea Floor, Part I. Cambridge University Press, 9-31.

Gales, N.J., Burton, H.R., 1989. The past and present status of the southern elephant seal Mirounga leonina (Linn.) in Greater Antarctica. Mammalia, 53, 35-47.

Guinet, C., Koudil, M., Bost, C-A., Durbec, J.P., Georges, J.Y., Mouchot, M.C., Jouventin , P., 1997. Foraging behaviour of satellite-tracked king penguins in relation to sea-surface temperatures obtained by satellite telemetry at Crozet Archipelago, a study during three austral summers. Marine Ecology Progress Series 150, 11-20.

Guinet, C., Dubroca, L., Lea, M.A., Goldsworthy, S., Cherel, Y., Duhamel, G., Bonadonna, F., Donnay, J.P., 2001. Spatial distribution of foraging in female Antarctic fur seals Arctocephalus gazella in relation to oceanographic variables: a scale-dependent approach using geographic information systems. Marine Ecology Progress Series 219, 251-264. 
Hindell, M.A., Burton, H.R., Slip, D.J., 1991a. Foraging areas of southern elephant seals, Mirounga leonina, as inferred from water temperature data. Australian Journal of Marine Freshwater Research 42, 115-128.

Hindell, M.A., Slip, D.J., Burton, H.R., 1991b. The diving behaviour of adult male and female southern elephant seals, Mirounga leonina (Pinnipedia : Phocidae). Australian Journal of Zoology 39, 595-619.

Jacobs, S.S., 1991. On the nature and significance of the Antarctic Slope Front. Journal of Marine Chemistry 35, $9-24$.

Jonker, F.C., Bester, M. N., 1998. Seasonal movements and foraging areas of adult southern female elephant seals, Mirounga leonina, from Marion Island. Antarctic Science 10, 21-30.

Ihaka, R., Gentleman, R., 1996. R : a language for data analysis and graphics. Journal of Computational and Graphical Statistics 5, 299-314.

Klyausov, A.V., 1993. On the frontal zone near the northern boundary of sea ice distribution in the Southern Ocean. Oceanology, English Translation 33, 727-734

Le Boeuf, B.J., Naito, Y., Asaga, T., Crocker, D.E., Costa, D.P., 1992. Swim speed in a female northern elephant 459 seal: metabolic and foraging implications. Canadian Journal of Zoology 70, 786-795.

Lesage, V., Hammill, M.O., Kovacs, K.M., 1999. Functional classification of harbor seal (Phoca vitulina) dives using depth profiles, swimming velocity, and an index of foraging success. Canadian Journal of Zoology 77, 74-87.

Loeb, V., Siegel, V., Holm-Hansen, O., Hewitt, R., Fraser, W., Trivelpiece, W., Trivelpiece, S., 1997. Effects of 467

Matthiopoulos, J., McConnell, B.J., Duck, C.D., Fedak, M.A., 2004. Using satellite telemetry and aerial counts to estimate space use by grey seals around the British Isles. Journal of Applied Ecology 41, 476-491.

McConnell, B.J., Chambers, C., Fedak, M. A., 1992. Foraging ecology of southern elephant seals in relation to the bathymetry and productivity of the Southern Ocean. Antarctic Science 4, 393-398.

McConnell, B.J., Fedak, M.A., 1996. Movements of southern elephant seals. Canadian Journal of Zoology 74, $1485-1496$. 
McMahon, C.R., Bester, M.N., Burton, H.R., Hindell, M.A., Bradshaw, C.J.A., 2005a. Population status, trends and a re-examination of the hypotheses explaining the recent declines of the southern elephant seal Mirounga leonina. Mammal Review 35, 82-100.

McMahon, C.R., Autret, E., Houghton, J.D.R., Lovell, P., Myers, A.E., Hays., G.C., 2005b. Animal borne sensors successfully capture the thermal properties of ocean basins. Limnology and Oceanography Methods 3, 392-398.

Pakhomov, E.A., McQuaid, C. D., 1996. Distribution of surface zooplankton and seabirds across the Southern

Park, Y.H., Gamberoni, L., Charriaud, E., 1993. Frontal structure, water masses, and circulation in the Crozet Basin. Journal of geophysical research 98, 12,361-12,385.

Park, Y.H., Charriaud, E., Fieux, M., 1998a. Thermohaline structure of the Antarctic Surface Water / Winter Water in the Indian sector of the Southern Ocean. Journal of Marine Systems 17, 5-23.

Park, Y.H., Charriaud, E., Ruiz Pino, D., Jeandel, C., 1998b. Seasonal and interannual variability of the mixed layer properties and steric height at station KERFIX, southwest of Kerguelen. Journal of Marine Systems 17, 571-586.

Reid, K., Croxall, J.P., 2001. Environmental response of upper trophic-level predators reveals a system change in 503

Schreer, J.F. and Testa, J.W. 1996., Classification of Weddell seal diving behavior. Marine Mammal Science 12, 227-250.

Schreer, J.F., Kovacs, K.M., O'Hara Hines, R.J., 2001. Comparative diving patterns of pinnipeds and seabirds. Ecological Monographs 71, 137-162.

Slip, D.J., 1995. The diet of southern elephant seals Mirounga leonina) from Heard Island. Canadian Journal of Zoology 73, 1519-1528.

Smith, W.O., Nelson, D.M., 1985. Phytoplancton bloom produced by a receding ice edge in the Ross Sea: spatial 
519 Smith, W.H.F., Sandwell, D.T., 1997. Global seafloor topography from satellite altimetry and ship depth soundings, Science 277, 1957-1962.

521

522

Weimerskirch, H., 1998. Foraging strategies of Indian Ocean albatrosses and their relationship with fisheries. In:

523 G. Robertson, R. Gales (Eds.), Albatross: biology and conservation, Surrey Beatty \& Sons, Chipping

524 Norton, 168-179.

525

526 
Figure 1:

527 a) Schematic representation of a reconstructed time-depth profile, showing the inflection points stored and transmitted by the Satellite Relay Data Logger (SRDL). Slopes used in dive classification are determined for each section $\left(\mathrm{S}_{1}=(\mathrm{d} 1-\mathrm{d} 2) /(\mathrm{t} 2-\mathrm{t} 1), \mathrm{S}_{2}=(\mathrm{d} 2-\mathrm{d} 3) /(\mathrm{t} 3-\mathrm{t} 2) \ldots\right)$,

530 as for vertical distances $(\mathrm{D} 1=|\mathrm{d} 1-\mathrm{d} 2|, \mathrm{D} 2=|\mathrm{d} 2-\mathrm{d} 3| \ldots)$.

531 b) Schematic representation of the 6 different dive classes obtained.

Figure 2: Vertical temperature section obtained by kriging temperature data recorded by

534 individual $n^{\circ} 1$ (see Fig 3 a) from Kerguelen to Antarctica (Marsh to April 2004). Position of 535 the hydrological fronts and identification of the three different kinds of habitats: Polar Front 536 (PF), Antarctic Divergence (AD), Antarctic Slope Front (ASF).

Figure 3:

539 a) Tracks followed by all the individuals (numbers correspond to comments in text). Each 540 colour is associated to one animal. Isobaths are represented every $500 \mathrm{~m}$.

541 b) Pattern of movements represented by distance from Kerguelen against time $(\mathrm{M}=$ males ; $\mathrm{F}$ $542=$ females).

544 Figure 4:

545 a) Relationship between the distance of the ice edge to the continent and the distance of 546 animals to the continent. The eight individuals presented here were monitored during thirteen 547 successive weeks.

548 b) Location of elephant seals just at the beginning of the winter period and thirteen weeks 549 later. Ground resolution of sea ice concentration is $6.25 \mathrm{~km} \times 6.25 \mathrm{~km}$. 
a)

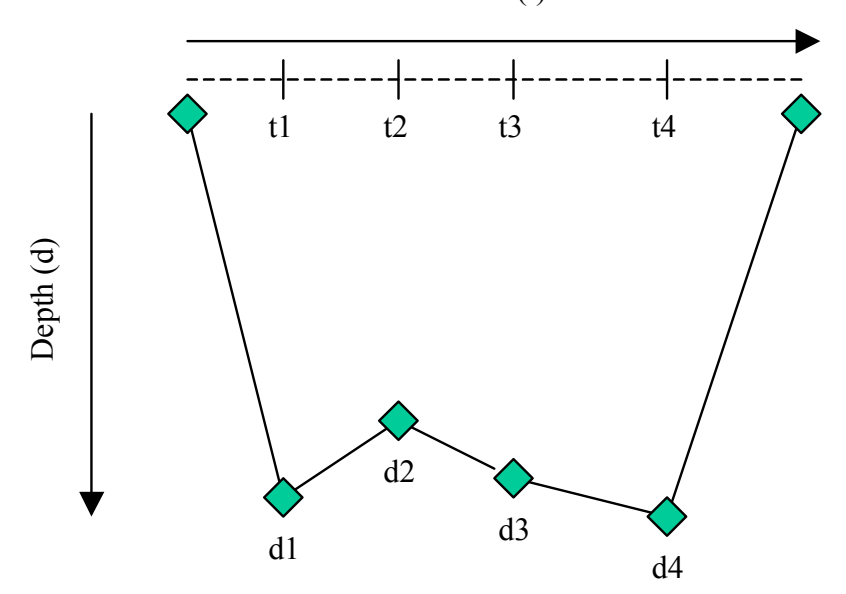

b)

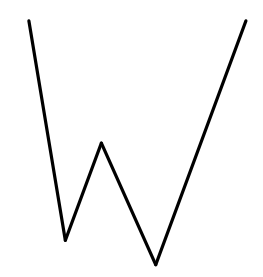

W-shape

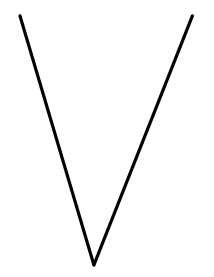

V-shape

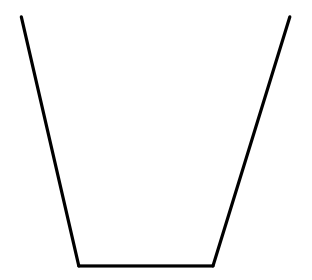

Square dives

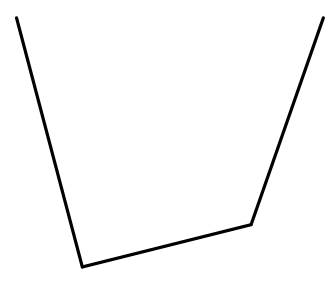

Drift dives

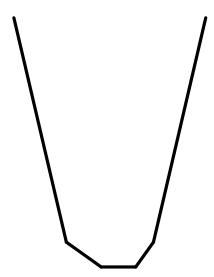

U-shape

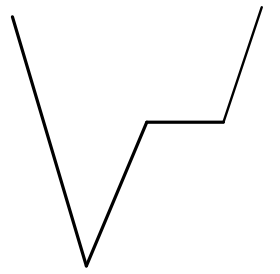

Square Root-shape (SqR-shape)

561

562

$563 \quad$ Fig 1 


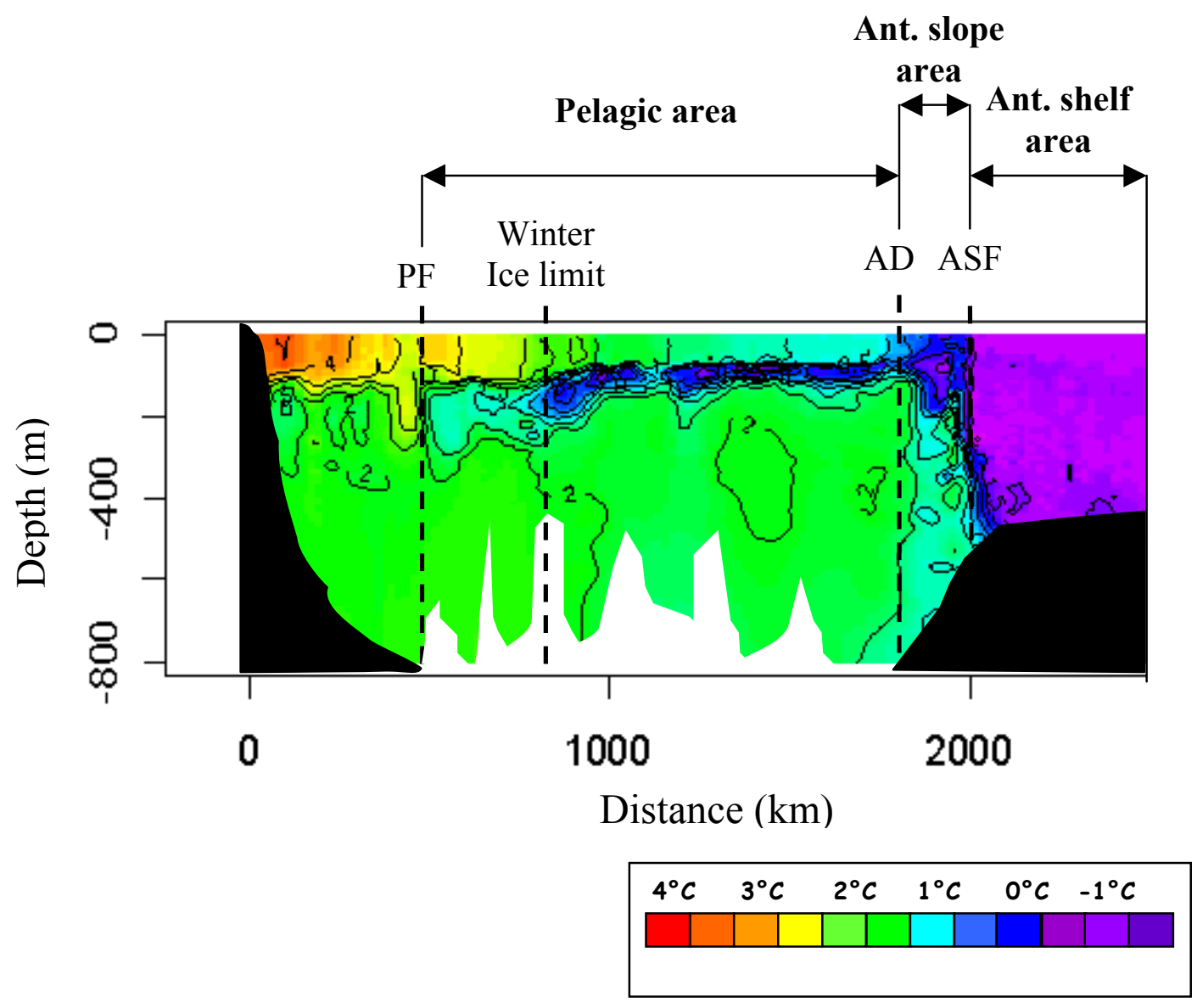

Fig 2 


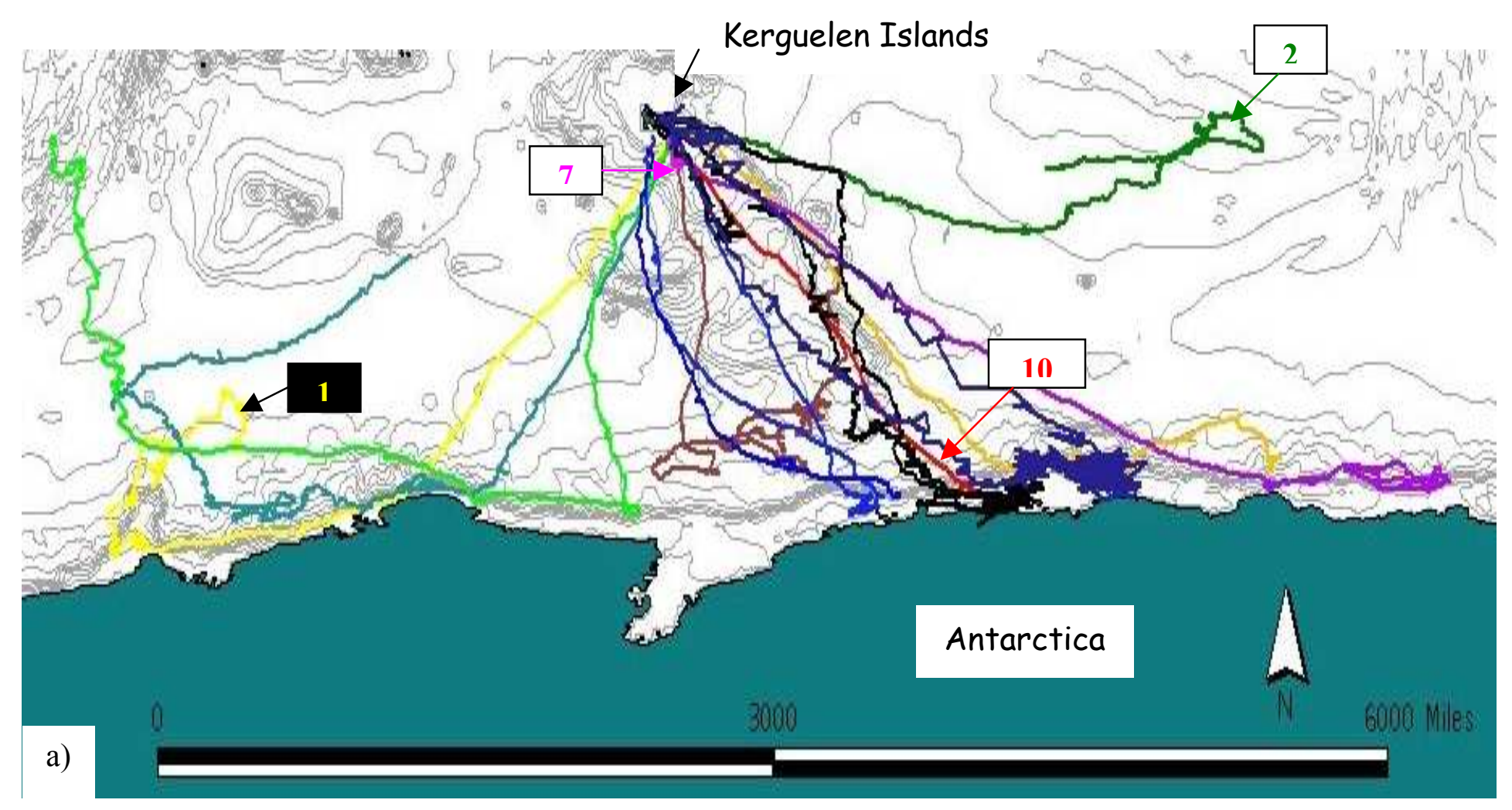

a)

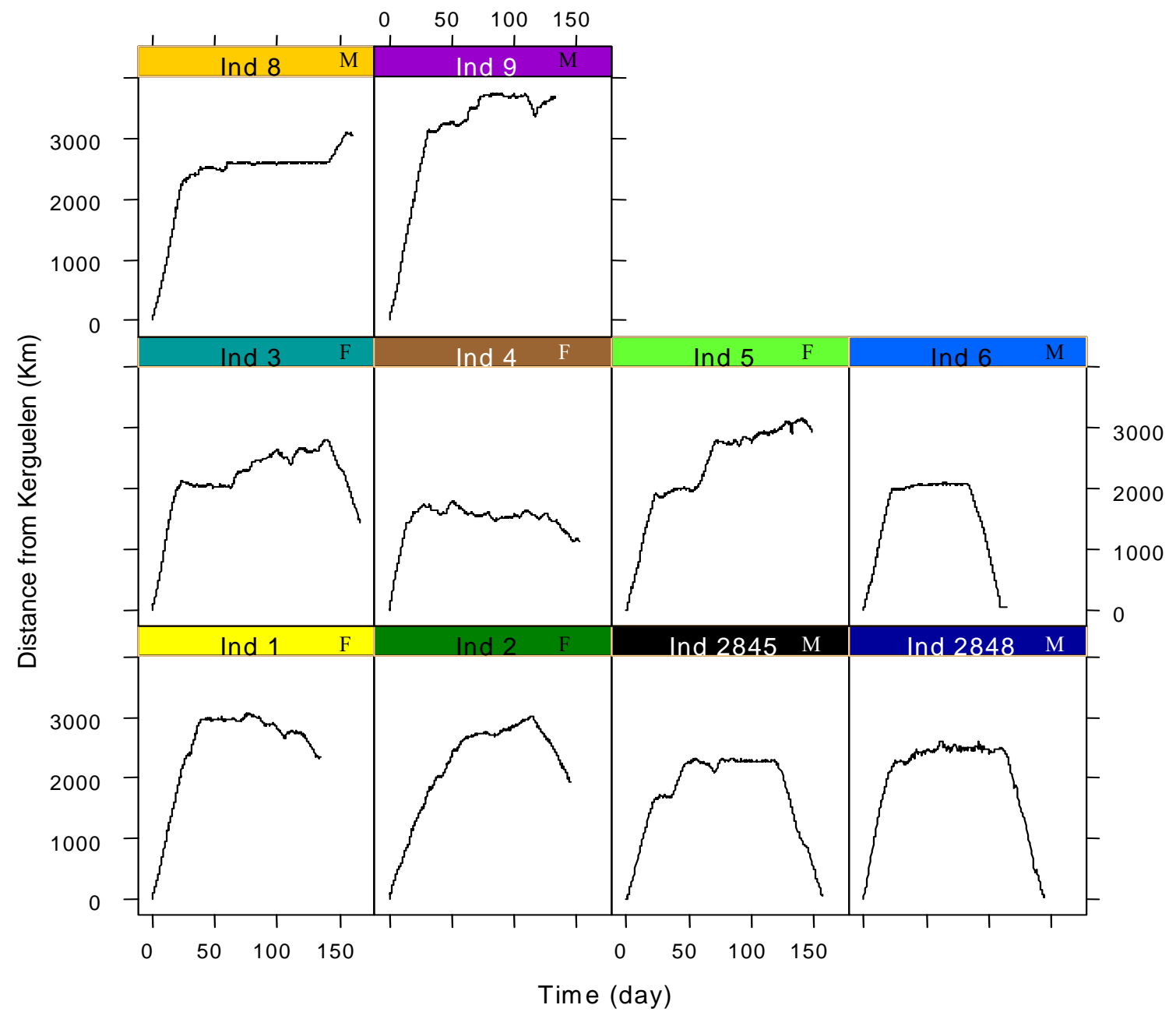

Fig 3 


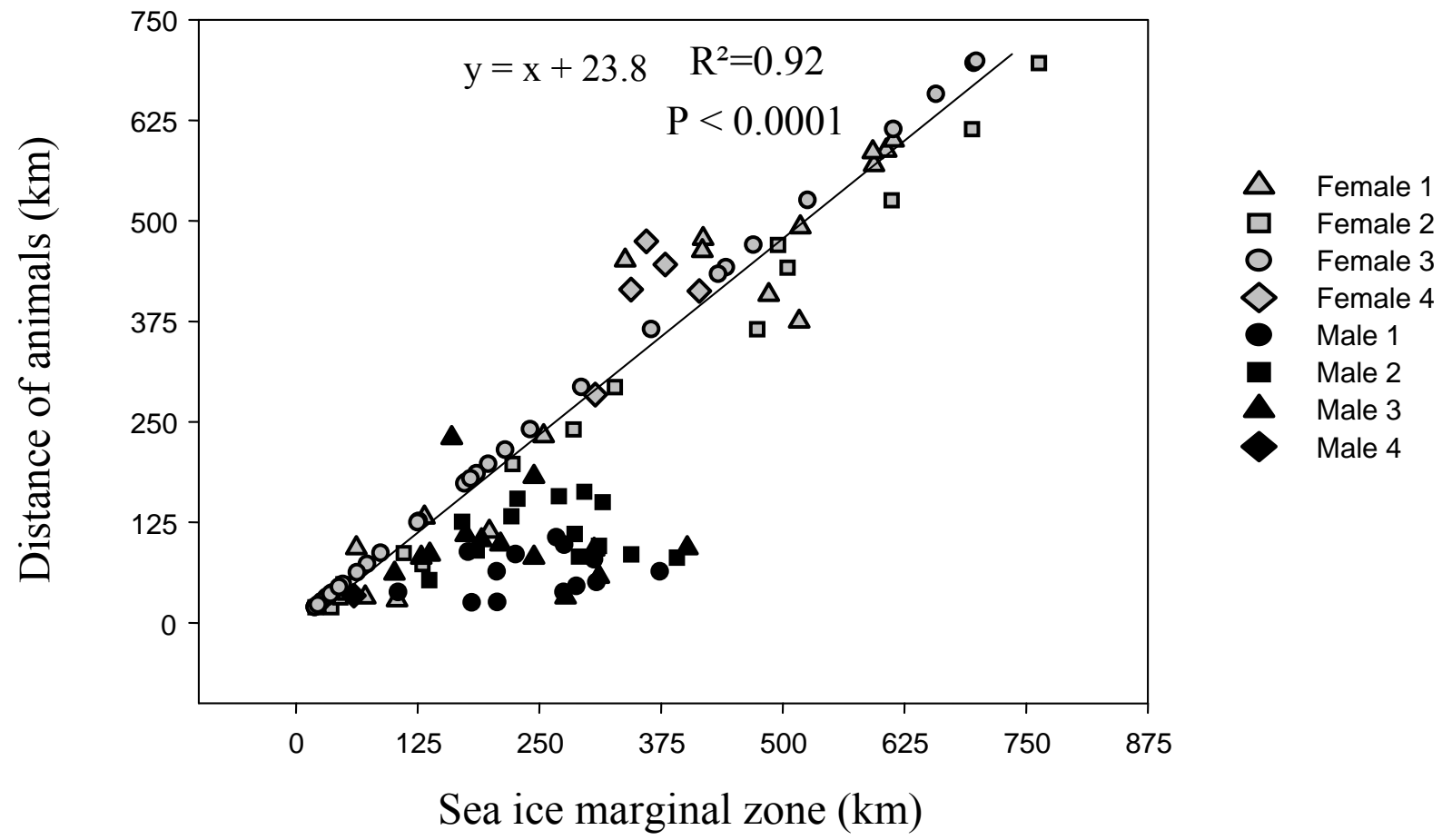

a)
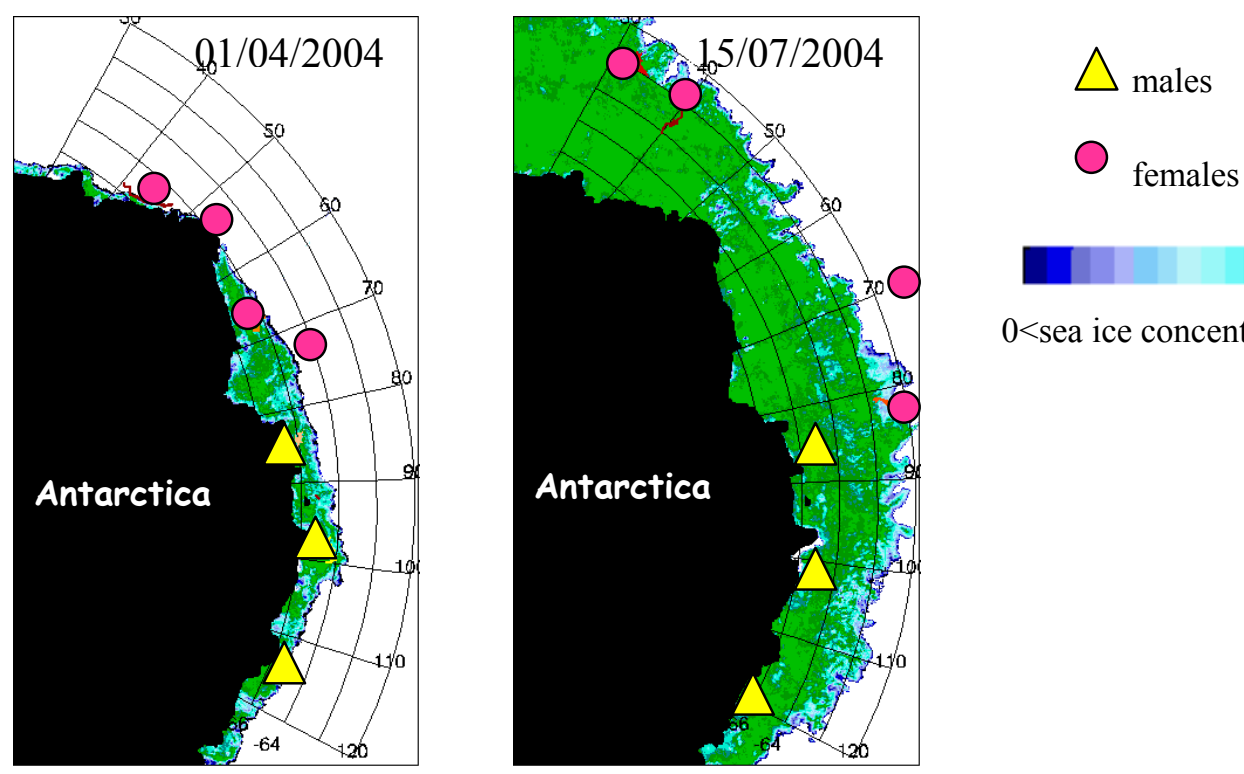

$0<$ sea ice concentration $<100 \%$

b)

Fig 4 


\begin{tabular}{|c|c|c|c|c|c|c|c|c|c|c|c|}
\hline Ind & Sex & Area & $\begin{array}{c}\text { Max depth } \\
(\mathrm{m})\end{array}$ & $\begin{array}{c}\text { Dive duration } \\
(\mathrm{sec})\end{array}$ & $\begin{array}{c}\text { Bottom time } \\
(\mathrm{sec})\end{array}$ & $\begin{array}{c}\text { U-shape } \\
(\%)\end{array}$ & $\begin{array}{c}\text { V-shape } \\
(\%)\end{array}$ & $\begin{array}{c}\text { W-shape } \\
(\%)\end{array}$ & $\begin{array}{c}\text { R-shape } \\
(\%)\end{array}$ & $\begin{array}{c}\text { SQ-shape } \\
(\%)\end{array}$ & $\begin{array}{c}\text { DR-shape } \\
(\%)\end{array}$ \\
\hline \multirow{3}{*}{$1:$} & \multirow{3}{*}{$\mathrm{F}$} & (Pelagic (Pel) & $390 \pm 200$ & $1052 \pm 308$ & $495 \pm 200$ & 44.6 & 12.3 & 27.7 & 12.3 & 1.6 & 1.5 \\
\hline & & Talus (Tal) & $428 \pm 165$ & $1272 \pm 600$ & $617 \pm 332$ & 56.3 & 9.3 & 9.4 & 3.1 & 9.4 & 12.5 \\
\hline & & Plateau (Pla) & $407 \pm 142$ & $997 \pm 285$ & $482 \pm 165$ & 56.5 & 8.7 & 7.6 & 10.9 & 8.7 & 7.6 \\
\hline \multirow[t]{2}{*}{$2:$} & \multirow[t]{2}{*}{$\mathrm{F}$} & $\{\quad$ Pel & $487 \pm 195$ & $1859 \pm 772$ & $933 \pm 603$ & 29.4 & 5.5 & 39.1 & 20.9 & 0.9 & 4.2 \\
\hline & & Pel & $249 \pm 156$ & $818 \pm 200$ & $421 \pm 193$ & 49.1 & 5.7 & 18.8 & 22.6 & 0 & 3.8 \\
\hline \multirow[t]{2}{*}{$3:$} & \multirow[t]{2}{*}{$\mathrm{F}$} & Tal & $492 \pm 146$ & $984 \pm 210$ & $483 \pm 181$ & 60.5 & 7.0 & 4.6 & 16.3 & 4.6 & 7.0 \\
\hline & & $\mathrm{Pla}$ & $296 \pm 137$ & $866 \pm 326$ & $467 \pm 269$ & 48.2 & 5.3 & 17.8 & 16.2 & 1.8 & 10.7 \\
\hline \multirow[t]{2}{*}{$4:$} & \multirow[t]{2}{*}{$\mathrm{F}$} & Pel & $386 \pm 227$ & $1091 \pm 342$ & $464 \pm 192$ & 50.5 & 7.1 & 18.2 & 19.2 & 0 & 5.0 \\
\hline & & Pel & $351 \pm 183$ & $971 \pm 276$ & $439 \pm 250$ & 31.2 & 6.4 & 31.2 & 27.5 & 0 & 3.7 \\
\hline \multirow[t]{3}{*}{$5:$} & \multirow[t]{2}{*}{$\mathrm{F}$} & Tal & $620 \pm 353$ & $1065 \pm 191$ & $419 \pm 70$ & 0 & 50 & 0 & 50 & 0 & 0 \\
\hline & & $\mathrm{Pla}$ & $236 \pm 53$ & $939 \pm 178$ & $616 \pm 183$ & 42.8 & 0 & 14.3 & 19 & 16.7 & 7.2 \\
\hline & \multirow{3}{*}{ M } & Pel & $288 \pm 212$ & $928 \pm 483$ & $405 \pm 263$ & 61.2 & 7.5 & 20 & 8.7 & 1.3 & 1.3 \\
\hline \multirow[t]{3}{*}{$6:$} & & Tal & $343 \pm 147$ & $611 \pm 151$ & $258 \pm 79$ & 44 & 20 & 16 & 16 & 0 & 4 \\
\hline & & Pla & $311 \pm 213$ & $727 \pm 362$ & $346 \pm 241$ & 48 & 13 & 20 & 10 & 7 & 2 \\
\hline & \multirow{3}{*}{$\mathrm{M}$} & Pel & $445 \pm 258$ & $1371 \pm 772$ & $608 \pm 472$ & 33.8 & 13.2 & 25 & 25 & 3 & 0 \\
\hline \multirow[t]{3}{*}{ 8: } & & Tal & $473 \pm 241$ & $1462 \pm 755$ & $638 \pm 478$ & 40.9 & 9.1 & 36.4 & 4.5 & 0 & 9.1 \\
\hline & & $\mathrm{Pla}$ & $344 \pm 184$ & $1314 \pm 662$ & $769 \pm 500$ & 39.6 & 5.9 & 23.7 & 18.4 & 4.7 & 7.7 \\
\hline & \multirow{3}{*}{ M } & Pel & $435 \pm 228$ & $1299 \pm 539$ & $636 \pm 352$ & 57.8 & 7.2 & 8.9 & 13.9 & 8.3 & 3.9 \\
\hline \multirow[t]{3}{*}{$9:$} & & Tal & $456 \pm 148$ & $1152 \pm 326$ & $646 \pm 260$ & 39.4 & 6.1 & 7.6 & 15.1 & 21.2 & 10.6 \\
\hline & & $\mathrm{Pla}$ & $373 \pm 130$ & $1125 \pm 435$ & $713 \pm 334$ & 29.4 & 5.9 & 2.9 & 8.8 & 38.3 & 14.7 \\
\hline & \multirow{3}{*}{$\mathrm{M}$} & Pel & $396 \pm 194$ & $1225 \pm 688$ & $555 \pm 425$ & 44.2 & 17.3 & 15.4 & 15.4 & 3.8 & 3.9 \\
\hline \multirow[t]{3}{*}{$2845:$} & & Tal & $369 \pm 350$ & $956 \pm 637$ & $384 \pm 327$ & 50 & 12.5 & 0 & 25 & 12.5 & 0 \\
\hline & & $\mathrm{Pla}$ & $395 \pm 164$ & $1359 \pm 390$ & $782 \pm 375$ & 35.4 & 2.1 & 22.9 & 20.8 & 10.4 & 8.4 \\
\hline & \multirow{3}{*}{ M } & Pel & $425 \pm 253$ & $1297 \pm 910$ & $604 \pm 467$ & 58.3 & 8.4 & 12.5 & 20.8 & 0 & 0 \\
\hline \multirow[t]{2}{*}{$2848:$} & & Tal & $637 \pm 316$ & $1790 \pm 1139$ & $717 \pm 294$ & 40 & 0 & 20 & 20 & 20 & 0 \\
\hline & & Pla & $434 \pm 124$ & $1261 \pm 450$ & $764 \pm 379$ & 63.1 & 7.9 & 13.1 & 0 & 10.6 & 5.3 \\
\hline
\end{tabular}

Table 1 : Average \pm SD of maximum dive depth, dive duration, time spent at the bottom of dive and proportion of the different dive shapes used according to areas visited for each individual. 